\title{
MODIFICATION OF SHOE BRAKE MACHINING PROCESS
}

\author{
Kaustubh Ghavte ${ }^{1}$, Tejas Katkar ${ }^{2}$, Bhushan $\operatorname{Jog}^{3}$, A.Kadir Bhore ${ }^{4}$, Mahesh Kale \\ ${ }^{1}$ Mechanical Department, VPM's MPCOE Velneshwar, Mumbai University \\ ${ }^{2}$ Mechanical Department, VPM's MPCOE Velneshwar, Mumbai University \\ ${ }^{3}$ Mechanical Department, VPM's MPCOE Velneshwar, Mumbai University \\ ${ }^{4}$ Mechanical Department, VPM's MPCOE Velneshwar, Mumbai University \\ ${ }^{5}$ Mechanical Department, VPM's MPCOE Velneshwar, Mumbai University
}

\begin{abstract}
This paper represents the "Modification in machining process" in "Pethe Brake Motor Private Limited". This company manufacture a brakes but during manufacturing the casting cost of shoe of brake increases so to decrease casting cost modification of machining process is done. Existing Casting of large homogeneous piece which contain four shoe is done because of large casting various type of defects are occurred and handling is also difficult. So idea is that casting of separate shoe is done and for machining that four separate shoe at same time fixture are design, which help to decrease Casting cost.
\end{abstract}

Keywords: - Shoe Brake, Modification, Casting, Fixture

\section{INTRODUCTION}

\subsection{About Industry}

"PETHE BRAKE MOTORS PRIVATE LTD" is a private industry which was founded by Mr. Bhalchandra Pethe in 1969 and leaded by him. In year 1993 Mr. Amar Pethe, a qualified electrical and mechanical engineer joined Pethe Group. Their aim is to provide good quality products with effective cost. Now Pethe Brakes come long way about 50 years. They have experience as well as outstanding industry knowledge and extensive application in this field. Today PBMPL work at 15000 sq. feet with 67 people at Guhagar. The products which this industry manufactures are spring loaded electrically released brakes, electrically released brakes, electrohydraulic thrustors. These brakes are used in escalator, EOT Crane and in machines where frequent $\mathrm{ON} / \mathrm{OFF}$ is required.

\subsection{About Project}

A brake shoe is the part of a braking system which carries the brake lining in the drum brakes used on EOT Cranes, or the brake block in train brakes. The brake shoe carries the brake lining, which is riveted or glued to the shoe. When the brake is applied, the shoe moves and presses the lining against the outside of the drum. The friction between lining and drum provides the braking effort. Energy is dissipated as heat.

In manufacturing of shoe brake, casting is done of $\mathrm{c}$ which contain four shoe. Then the machining process is carried out on that casting and four shoe are separated. Working on this, some problems are recognized as size of shoe brake increases various type of casting defects occurs like Blowholes, shrinkage defects, etc., handling of homogenous piece is difficult. And casting cost also increases. This effects on production rate and material loss also increases.

To overcome these problems modification in casting process is done that is, four separate shoe are casted and should undergo machining at same time this eliminates defects in casting and also easy to handle. For this fixture is design which carries four shoe.

\section{METHODOLOGY}

Recently all the operations perform on the homogenous piece contain four shoe using lathe machine. After all operations, they separate out the four shoe from the piece. By this manufacturing process large dimensions' shoe brake are difficult and material loss is more. 


\subsection{Existing Machining of Shoe Brake}

\section{Flowchart}
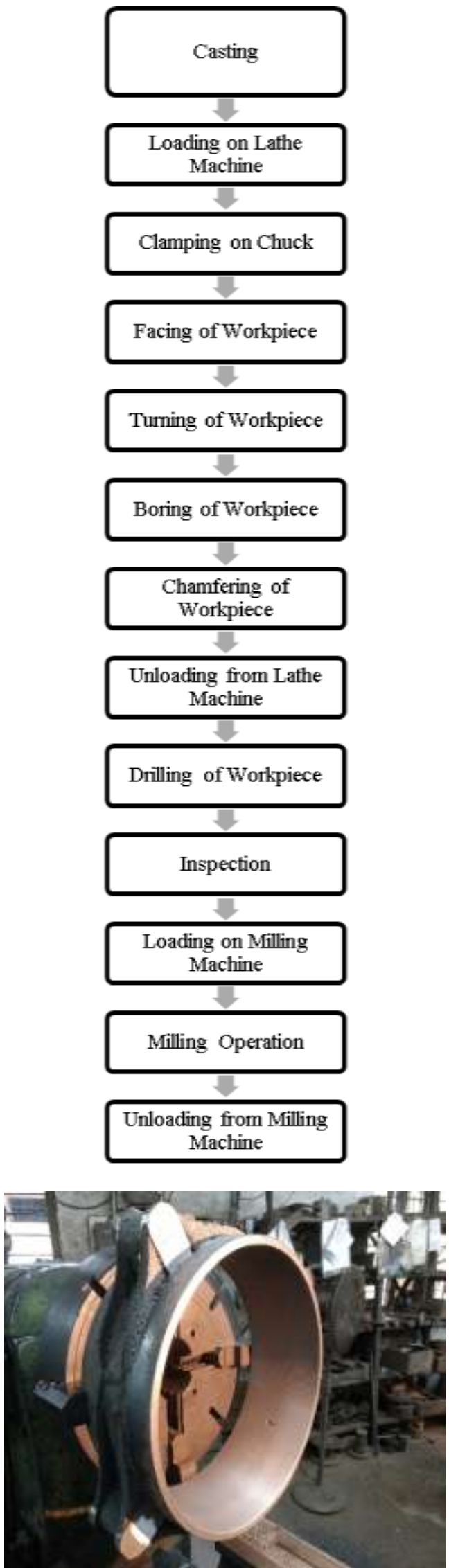

Fig. 2: Clamped Homogenous Piece

\subsection{Time Study of Existing Machining Process}

Table 1: Existing Time Study

\begin{tabular}{|l|l|l|l|l|}
\hline $\begin{array}{l}\text { Sr. } \\
\text { No. }\end{array}$ & Operations & \multicolumn{3}{|l|}{ Time } \\
\hline & & $\begin{array}{l}\text { Reading } \\
1 \text { (min) }\end{array}$ & $\begin{array}{l}\text { Reading } \\
2 \text { (min) }\end{array}$ & $\begin{array}{l}\text { Reading } \\
3 \text { (min) }\end{array}$ \\
\hline 1 & Loading & 10 & 15 & 15 \\
\hline 2 & Clamping & 25 & 23 & 26 \\
\hline 3 & Facing & 46.6 & 44.6 & 44 \\
\hline 4 & Turning & 20 & 20 & 22 \\
\hline 5 & Boring & 81 & 90 & 85 \\
\hline 6 & Chamfering & 18 & 23 & 22 \\
\hline 7 & Unloading & 5 & 7 & 6 \\
\hline 8 & Drilling & 50 & 52 & 53 \\
\hline 9 & Inspection & 25 & 26 & 26 \\
\hline 10 & $\begin{array}{l}\text { Clamping } \\
\text { on milling } \\
\text { machine }\end{array}$ & 15 & 14 & 15 \\
\hline 11 & Milling & 29 & 30 & 30 \\
\hline 12 & Unloading & 11 & 10 & 10 \\
\hline
\end{tabular}

\section{MODIFICATION}

The shoe is separately casted and facing is done on that shoe by milling machine than its clamped on fixture which is mounted on lathe.

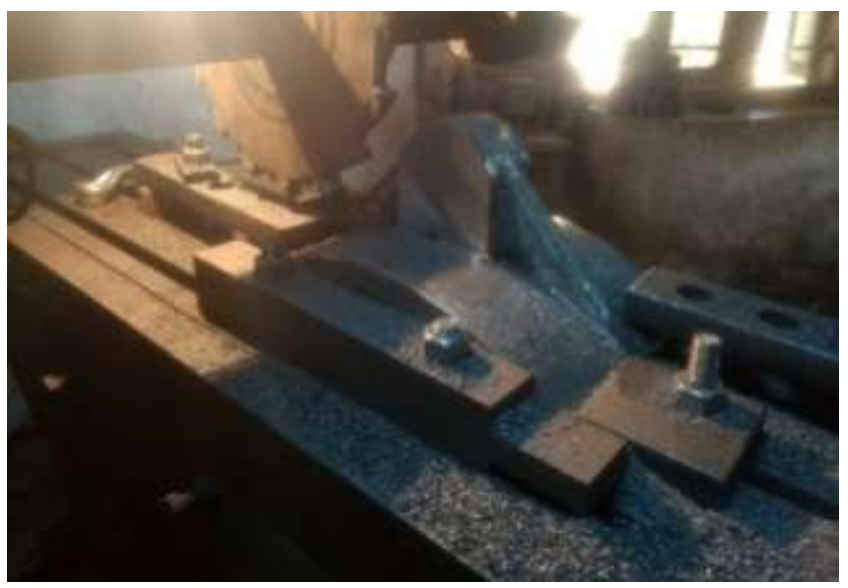

Fig 3: Facing operation on milling machine

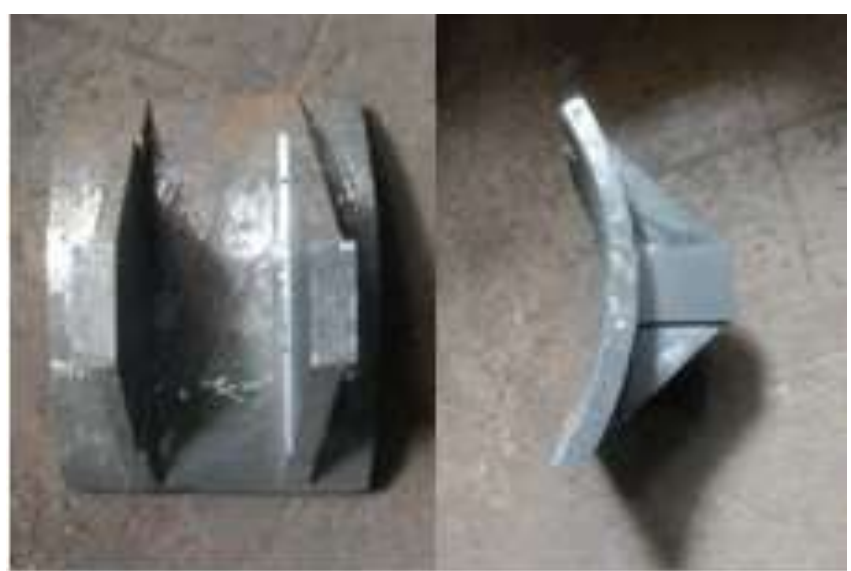

Fig 4: Separately casted shoe 
To perform simultaneously all machining operation on four shoe the fixture is design in that four-separately casted shoe are clamped and the fixture is mounted on to the lathe machine.

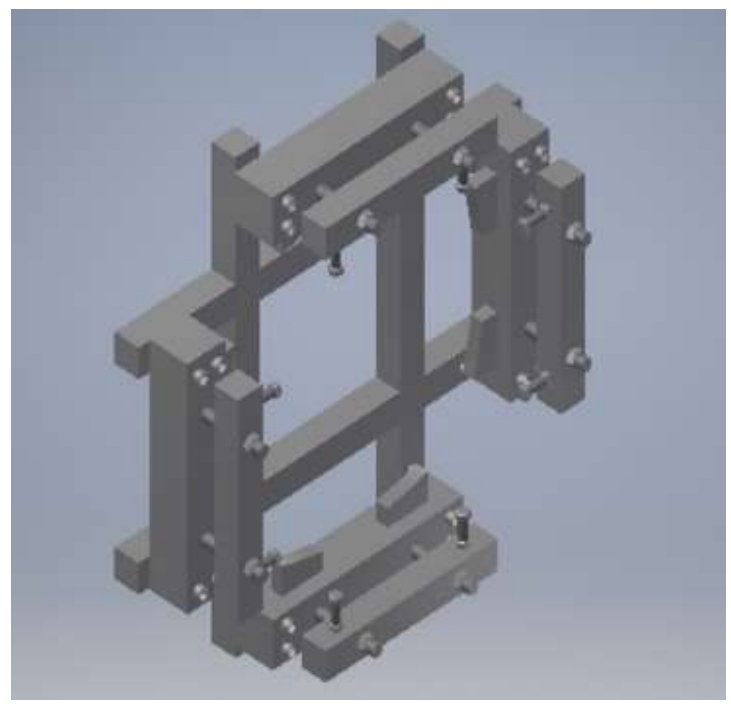

Fig 5: CAD drawing of fixture

\subsection{Modified Machining Process Shoe Brake}

\section{Flowchart}

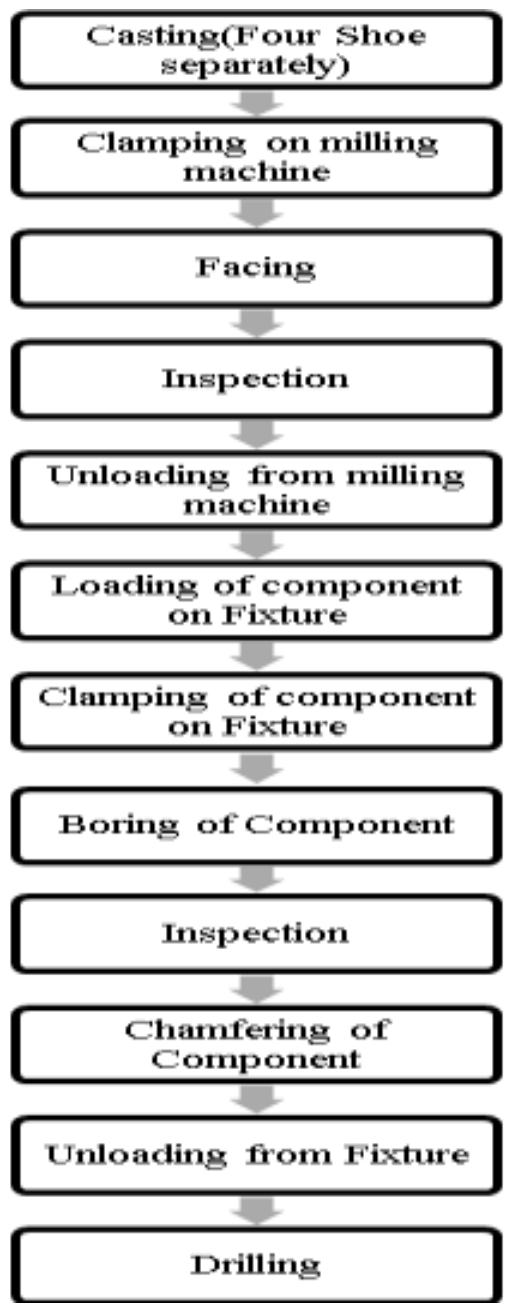

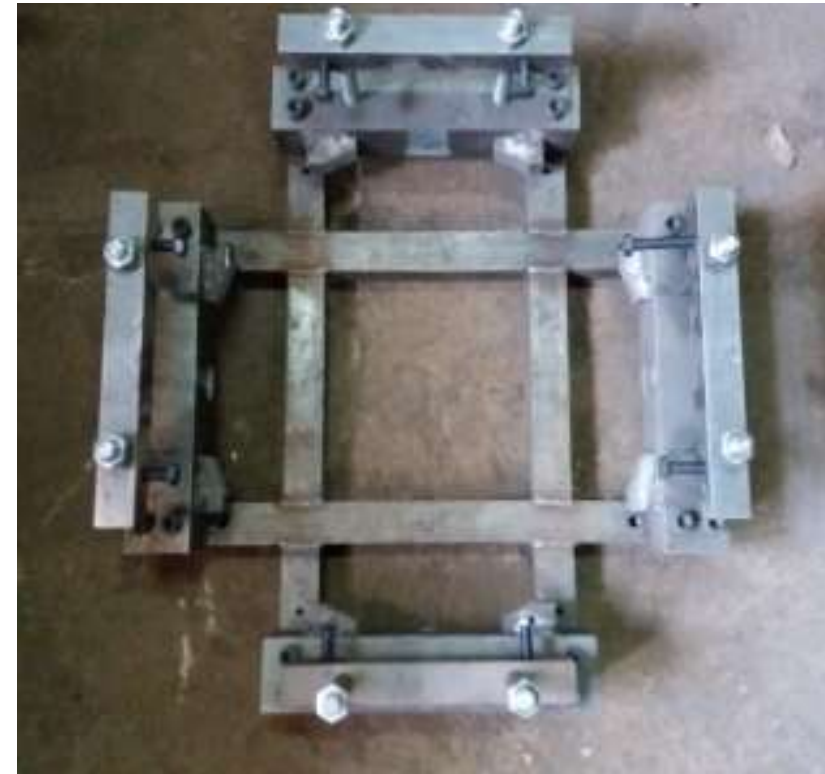

Fig 6: Fixture

\subsection{Time Study of Modified Machining Process}

\section{Shoe Brake}

Table 2: Modified Machining Process Time Study

\begin{tabular}{|c|c|c|c|c|}
\hline \multirow{2}{*}{$\begin{array}{l}\text { Sr. } \\
\text { No. }\end{array}$} & \multirow[t]{2}{*}{ Operations } & \multicolumn{3}{|l|}{ Time } \\
\hline & & $\begin{array}{l}\text { Reading } \\
1 \text { (min) }\end{array}$ & $\begin{array}{l}\text { Reading } \\
2 \text { (min) }\end{array}$ & $\begin{array}{l}\text { Reading } \\
3 \text { (min) }\end{array}$ \\
\hline 1 & $\begin{array}{l}\text { Clamping } \\
\text { on milling } \\
\text { machine }\end{array}$ & 0.87 & 0.86 & 0.85 \\
\hline 2 & Facing & 27 & 25 & 27 \\
\hline 3 & Inspection & 2 & 1 & 1.8 \\
\hline 4 & $\begin{array}{l}\text { Unloading } \\
\text { from } \\
\text { milling } \\
\text { machine }\end{array}$ & 0.13 & 0.21 & 0.15 \\
\hline 5 & $\begin{array}{l}\text { Loading on } \\
\text { fixture }\end{array}$ & 8 & 9 & 8 \\
\hline 6 & Clamping & 30 & 31 & 31 \\
\hline 7 & Boring & 80 & 81 & 82 \\
\hline 8 & Inspection & 19 & 20 & 21 \\
\hline 9 & Chamfering & 20 & 21 & 20 \\
\hline 10 & Unloading & 10 & 11 & 10 \\
\hline 11 & Drilling & 40 & 41 & 42 \\
\hline
\end{tabular}




\section{RESULT AND ANALYSIS}

\subsection{Time Analysis between Existing and Modified}

\section{Machining Process}

Table 3: Comparison between Existing and Modified Machining Process

\begin{tabular}{|l|l|l|l|}
\hline Sr. No. & $\begin{array}{l}\text { Average } \\
\text { time taken }\end{array}$ & $\begin{array}{l}\text { For } \\
\text { existing } \\
\text { Process } \\
(\mathrm{min})\end{array}$ & $\begin{array}{l}\text { For } \\
\text { proposed } \\
\text { Process } \\
(\mathrm{min})\end{array}$ \\
\hline 1 & Loading & 14 & 9 \\
\hline 2 & $\begin{array}{l}\text { Clamping } \\
\text { on lathe and } \\
\text { milling } \\
\text { machine }\end{array}$ & 40 & 31 \\
\hline 3 & Facing & 46 & 26 \\
\hline 4 & Turning & 22 & 0 \\
\hline 5 & Boring & 85 & 80 \\
\hline 6 & Inspection & 26 & 22 \\
\hline 7 & Chamfering & 21 & 20 \\
\hline 8 & Unloading & 16 & 11 \\
\hline 9 & Drilling & 52 & 40 \\
\hline
\end{tabular}

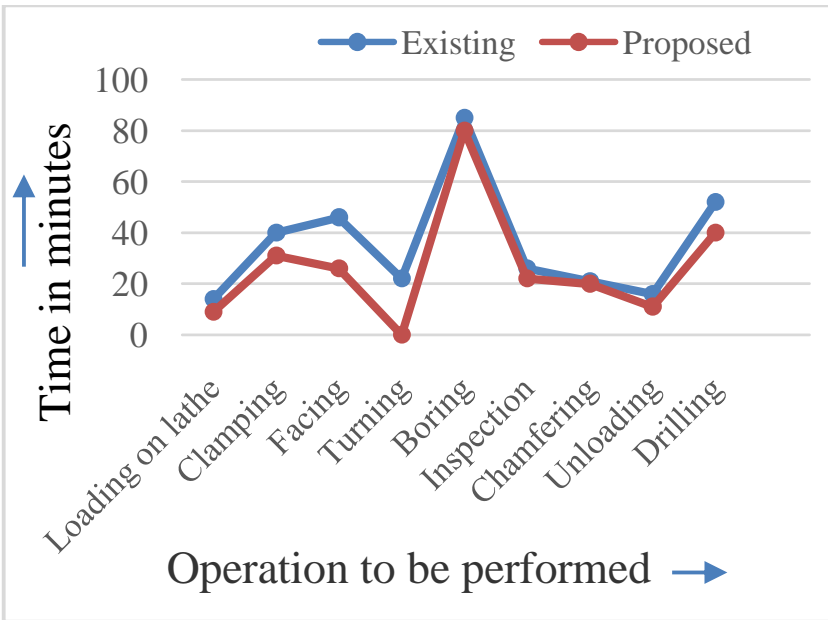

Fig 7: Time analysis of existing and modified machining process

1. Average total time required for existing machining process is $322 \mathrm{~min}$ that is $5.36 \mathrm{hr}$.

2. Average total time required for modified machining process is $239 \mathrm{~min}$ that is $3.98 \mathrm{hr}$.

3. As the total machining time required for modified machining process is less than the total time required for existing machining process so the production rate also increases in modified machining process.

\section{WEIGHT ANALYSIS}

In existing manufacturing process, the weight before machining is $36 \mathrm{~kg}$ and after machining weight is $30 \mathrm{~kg}$ so material loss is $6 \mathrm{~kg}$. But in modified machining process the weight before machining is $34.2 \mathrm{~kg}$ and after machining weight is $30.4 \mathrm{~kg}$ so material loss is $3.8 \mathrm{~kg}$.

\section{CONCLUSION}

\subsection{Production per hour for Existing and Modified}

\section{Machining Process}

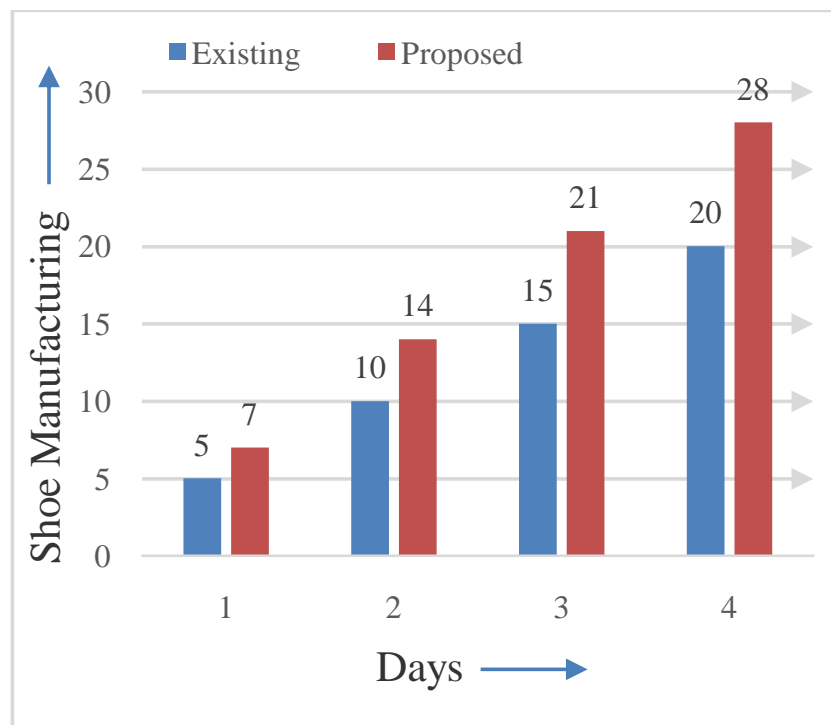

Fig 8: Production per hour for existing and modified machining process

\subsection{Productivity Comparison}

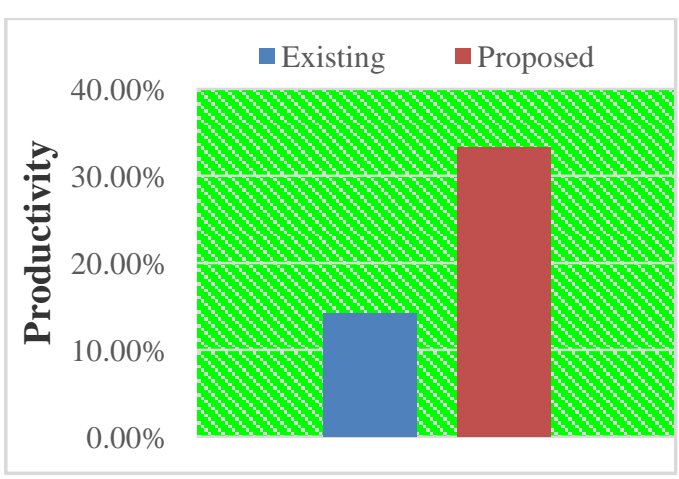

Fig 9: Productivity

By above graphs its clearly seen that by using modified machining process production rate and productivity increases

\section{REFERENCES}

[1] www.pethe.in

[2] D.S. Deshmukh and Shankar Madanmohan, Design Evaluation and Material Optimization of a Train Brake, IJRSSET, Volume 1, Issue 2, May 2014, PP45-49

[3] Ahmet Akkus and Mukadder Yegin, Reserch on Wear Rate and Mechanical Properties of Brake Sabot Used in Railway Rolling Stocks, IJAST, Vol. 4, No. 7, December 2014

[4] Ambikaprasad O. Chaubey and Abhijeet A. Raut, Review Paper on Brake Shoe Failure, IJRASET, Vol.04, Issue V, May 2016 